\title{
THE NON BIS IN IDEM PRINCIPLE IN THE CASE LAW OF THE COURT OF JUSTICE OF THE EUROPEAN UNION - CONSISTENCY OR INCONSISTENCY?
}

\section{D.D. PĂTRĂUŞ}

\author{
Darius-Dennis Pătrăuș \\ Faculty of Law \\ University “Babeș-Bolyai”, Cluj-Napoca, Romania \\ Email: darius_patraus@hotmail.com
}

\begin{abstract}
The non bis in idem principle was first established in the Hammurabi Code (2,500 $B C)$, under the name of res judicata pro veritate habetur.According to the non bis in idem principle, "no one is allowed to be summoned again in court or punished in another criminal case for the same criminal offense for which he has already been convicted or acquitted under the law of a state". The non bis in idem principle has a broad field of application in the field of international judicial cooperation in criminal matters.The harmonization of Member States' laws and the abolition of borders at EU level created the premises for the widespread application of the non bis in idem principle.For this reason, the Court of Justice of the European Union has been charged with interpreting the rule, namely the non bis in idem principle, as regulated in art. 54 CISA.At the present stage of regulation, an interpretation contrary to the non bis in idem principle would be likely to erode the right and affect international judicial cooperation in criminal matters.
\end{abstract}

KEYWORDS: non bis in idem principle; the Court of Justice of the European Union; res judicata; domestic law; EU law.

\section{BRIEF INTRODUCTION REGARDING THE NON BIS IN IDEM PRINCIPLE}

In current legal geography, we are witnessing the development and consolidation of the European law, which is becoming increasingly strong, in particular through the jurisprudence of the Court of Justice in Luxembourg, as a unitary system with the role of uniformizing national legal systems.

While criminal legislation does not, in principle, fall within the scope of the Union's competences, the European legislator may impose certain conduct on the Member States in this area, and the CJEU has the competence to deal with legal issues related to criminal law and criminal procedure law, in the light of the provisions of art. 258, art. 263 and art. 267 TFEU.

One of the principles created by the provisions of art. 50 CFREU $^{1}$, art. 54 CISA $^{2}$ and art. 4 of Protocol no. $7 \mathrm{ECHR}^{3}$ establishes at European level the non bis in idem rule. At the same time, the principle of non bis in idem is also provided by the European special

\footnotetext{
${ }^{1}$ Published in OJ C 303 of 14 December 2007. See also F.Marian, The Constitution of Romania. The European Convention on Human Rights. Charter of Fundamental Rights of the European Union. 5th Edition, PH. Rosetti International, 2016.p.116.

${ }^{2}$ Convention implementing the Schengen Agreement of 14 June 1985, signed in Luxembourg, 19 June 1990 , published in OJ L 239 of 22 September 2000.

${ }^{3}$ Ratified by Romania through Law no. 30/1994, publ. in Official Monitor (Of. M.) No.135 of 31 May 1994. Protocol no. 7 was amended by Protocol no. 11 of May 11, 1994, ratified by Romania by Law no. 79/1995, published in Of. M., no. 147 of July 13, 1995.
} 
legislation, in art. 7 of the Convention on the Protection of the Communities' Financial Interests ${ }^{4}$ and in art. 10 of the Convention on the Fight against Corruption ${ }^{5}$.

The aforementioned European provisions have also been reflected in the internal regulatory framework - art. 6 Criminal Procedure Code ${ }^{6}$. The principle is also regulated by the provisions of art. 421 (i) and the Criminal Code, as well as the legislation on judicial cooperation in criminal matters - art. $8^{7}$.

\section{APPLYING THE NON BIS IN IDEM PRINCIPLE IN CORRELATION WITH EUROPEAN NORMS}

Final judgments acquire judgmental authority, presuming to reflect the truth.

Prior to the entry into force of the New Code of Criminal Procedure, the non bis in idem principle, although not explicitly enshrined as a fundamental principle of the Romanian criminal trial, was recognized in the legal doctrine under the name of the principle of the authority of final judgment.

\section{A. Definition}

The non bis in idem principle was first established in the Hammurabi Code $(2,500$ $\mathrm{BC})$, under the name of res judicata pro veritate habetur ${ }^{8}$.

According to the non bis in idem principle, "no one is allowed to be summoned again in court or punished in another criminal case for the same criminal offense for which he has already been convicted or acquitted under the law and criminal procedure of a state."

Member States are prevented from judging a person twice for the same or the same acts or forcing a person to serve a sentence for the same deed.

In order to extract the essence of the non bis in idem principle, we must take into account the following key elements: the existence of a final criminal judgment on the merits of the case, the identity of persons (eadem personae), the identity of facts or facts that are substantially the same (idem factum).

The reason for which it has been inserted in the content of the European normative acts, but also in the national legislation, non bis in idem, which is raised in principle, derives from the necessity of legal certainty, which requires observance of the fundamental principle of res judicata. A criminal case, finally settled, can not be resumed indefinitely since the person judged may not be obliged to always live with the uncertainty that the criminal action may be reopened if no new evidence arises.

\section{B. Correlation of the non bis in idem principle with European secondary law}

The non bis in idem principle has a broad field of application in the field of international judicial cooperation in criminal matters.

A foreign court ruling may be recognized in Romania for the purpose of executing the sentence of detention of a person on the territory of Romania ${ }^{9}$ for the enforcement of criminal

\footnotetext{
${ }^{4}$ Published in OJ C 316 of 27 November 1995 (Council Act of 26 July 1995).

${ }^{5}$ Published in OJ L 287 of 29 October 2008 (Council Decision 2008/801 / EC of 25 September 2008).

${ }^{6}$ Law no. 135/2010, publ. In Of. M. no. 486 of July 15, 2010, modified by Law no. 255/2013 for the implementation of the New Criminal Procedure Code and for amending and completing some normative acts containing criminal procedural provisions, published In Of. M. 515 of August 14, 2013.

${ }^{7}$ Law no. 302/2004 republished, on judicial cooperation in criminal matters, Of. M., Part I, no. 377 of 31 May 2011, as amended and supplemented by Law no. 236/2017, published in Of. M. no. 993 of 14 December 2017.

${ }^{8}$ E. Molcuţ, D. Oancea, Romanian Law, Publishing House and Press Şanşa SRL, Bucharest, 1993, p.28 et seq.

${ }^{9}$ The procedure established by art. 137-138 of Law 302/2004 as amended by Council Framework Decision 2008/909 / JHA of 27 November 2008 on the application of the principle of mutual recognition of judgments in criminal matters imposing custodial sentences or measures involving deprivation of liberty for the purpose of their enforcement in the European Union European, published in OJ L series No.327 of 5 December 2008.
} 


\section{Darius-Dennis Pătrăuș}

and administrative penalties imposed by the judicial bodies ${ }^{10}$ in order to enforce foreign judgments of confiscation $^{11}$, and to produce effects other than punishment execution ${ }^{12}$. At the same time, the non bis in idem rule also affects other forms of judicial cooperation at European level.

Thus, the European Convention on Jurisdiction in Criminal Matters provides in art. The obligation of notification, i.e. the requested State, must inform the action taken and, where appropriate, send a copy of the sentence. If the bilateral treaties signed by the Member States exclude criminal prosecution in a State other than the State where the offense was committed in the case of non-prosecution on grounds of substantive law, the non bis in idem is used.

Also, the European Convention on Extradition provides in art. 9 that extradition can not be approved if the person which was being prosecuted has been finally tried, for the acts for which extradition is requested, by the competent authorities of the requested State. warrant ${ }^{13}$.

The non bis in idem principle also applies within the framework of the European arrest

The non bis in idem rule also applies in Union law, as is clear from the case-law of the CJEU.

\section{THE IMPORTANCE OF THE PRINCIPLE REFLECTED IN THE CASE-LAW OF THE CJEU}

The issue of the non bis in idem principle stems from the fact that it is not wellestablished at European level ${ }^{14}$.

Initially, the content of the non bis in idem ban was interpreted in two ways: a person finally convicted of a criminal act can no longer be prosecuted and punished again; the same person can no longer be convicted of the legal classification finally settled, but it could be for another legal classification.

The harmonization of Member States' laws and the abolition of borders at EU level created the premises for the widespread application of the non bis in idem principle ${ }^{15}$.

It should be noted that the right under this principle has the same meaning and scope both in Union law and in the corresponding law of the ECHR.

Article 6 of the Treaty on European Union (Lisbon version) provides that the rights, freedoms and principles enshrined in the Charter of Fundamental Rights of the European Union of 7 December 2000, which have the same legal value as the Treaties, are recognized in the $\mathrm{EU}^{16}$.

The CFREU provides in art. 50 the right of any person not to be tried or convicted twice for the same offense, namely the fact that no one can be tried or convicted for an

\footnotetext{
${ }^{10}$ Art. 139 of Law 302/2004.

${ }^{11}$ Article 140 of Law 302/2004 and Framework Decision 2006/783 / JHA of 6 October 2006 on the application of the principle of mutual recognition regarding confiscation orders, published in OJ L 328, 24.11.2006.

${ }^{12}$ Article 140/1 of Law 302/2004 and Council Framework Decision 2008/909 / JHA of 27 November 2008 on the application of the principle of mutual recognition of judgments in criminal matters imposing custodial sentences or measures involving deprivation of liberty for the purpose of enforcement in the EU, in OJ L 327 of 5 December 2008.

${ }^{13}$ Art. 98 para. 2 (b) of Law 302/2004 and Council Framework Decision 2002/584 / JHA of 13 June 2002 on the European arrest warrant and the surrender procedures between Member States, in OJ L 190, 18 July 2002. For details, see I. C. Morar, International Judicial Cooperation in Criminal Matters, Hamangiu Publishing House, 2014, p.10.

${ }^{14}$ F. Radu, International Judicial Cooperation in Criminal Matters. Guide for Practitioners, Wolters Kluwer Publishing House, Bucharest, 2009, p. 98-99.

${ }^{15}$ M. I. Rusu, Judicial Assistance in Criminal Matters at European Level, PH. Universul Juridic, Bucharest, 2015, p.30.

${ }^{16}$ Adopted on 12 December 2007 in Strasbourg, published in OJ C of 14 December 2007.
} 
offense for which he has already been acquitted or convicted within the Union by a final court decision in accordance with the law.

Convention Implementing the Schengen Agreement (CISA) in art. 54-57 refers to the non bis in idem principle. In art. 54 rules are laid down governing this principle - it excludes a new sanction, a new prosecution for the same deed without, however, defining legally the terms used by the Convention.

For this reason, the Court of Justice of the European Union has been charged with interpreting the rule, namely the non bis in idem principle, as regulated in art. 54 CISA.

Following the entry into force of the Treaty of Amsterdam ${ }^{17}$, the jurisdiction of the Court of Justice of the European Union, also deals with the issue of preliminary rulings on the validity and interpretation of normative acts issued by the Union institutions.

In the Gozutok $^{18}$ and Brugge $^{19}$ cases, the CJEU ruled that the non bis in idem principle is also applicable to criminal prosecution orders given by the prosecutor if, for example, the prosecutor has applied a pecuniary sanction executed by the accused, stating that art. 54 CISA should promote the dynamic process of European integration by creating an area of freedom and justice. In order to achieve this goal, cumulation of penalties should be avoided. The Court drew attention to the need for national prosecutor's offices to cooperate in the application of criminal law, not requiring the involvement of a court or pronouncing a sentence, by virtue of the need to respect the principle of mutual trust between states regarding their judicial systems, accept the enforcement of the criminal law in force in the other State, even if the application of its own law can lead to other solutions. Similarity of the type of sanction applied by the prosecutor in this casewith the administrative fines that could be applied under Romanian criminal procedural law ${ }^{20}$ is also obvious ${ }^{21}$.

In Miraglia ${ }^{22}$, the Court has stated that the non bis in idem principle would not prevent criminal proceedings being initiated in different countries, against the same suspect and for the same acts. When one of the actions is finalized by a final judgment, the non bis in idem principle will apply. Ordinances of criminal negligence, only on formal grounds, do not have the same effect, since what is essential is the content, not the fact that a criminal sentence or a resolution of non-prosecution has been pronounced. If the accused has already been prosecuted and the decision has a content comparable to that of a lawful ruling, the non bis in idem barrier will be dissolved.

In Gasparini and others ${ }^{23}$ and Van Straaten ${ }^{24}$, the Court held that an acquittal decision prevents a further prosecution if it is due to lack of evidence and also a decision closing the proceedings as a result of interference, in both situations the non bis in idem principle is to be applied.

In Turansky ${ }^{25}$, the Court has stated that in order to be able to find that a person has been the subject of a final judgment in respect of the facts imputed to him, the criminal

\footnotetext{
${ }^{17}$ Signed on 2 October 1997, in force since 1 May 1999.

${ }^{18}$ Case 187/01, judgment of 11 February 2003.

${ }^{19}$ Case 385/01, judgment of 11 February 2003.

${ }^{20}$ Art.91 (c) of the Criminal Code of 1969 and Article 10 (b)/1 Criminal Procedure Code of 1968 or art.318 Criminal Procedure Code, prior to the modifications made by art. II pt.82 of GEO no.18 / 2016 for amending and completing the Law no.286 / 2009 on the Criminal Code, Law no. 135/2010 on the Criminal Procedure Code, as well as for completing the art.31 paragraph 1 of the Law no.304 / 2004 on the judicial organization, published in Of. M. No.389 of May 23, 2016.

${ }^{21}$ D. I. Bugnariu, Aspects regarding the application of the non bis in idem principle in the criminal law practice of the European Court of Justice, European Legal Affairs Magazine no.2 / 2013, http://iaduer.ro/?p=1915, consulted on 27 December 2017, 13:00.

${ }^{22}$ Case 469/03, judgment of 10 March 2005. See also K. Ulrike et al., Judicial Cooperation in Criminal Matters, Phare Project 2005 / IBH / JH / 03, 2005. p.183.

${ }^{23}$ Case 467/04, judgment of 28 September 2006.

${ }^{24}$ Case 150/05, judgment of 28 September 2006.

${ }^{25}$ Case 491/07, judgment of 22 December 2008.
} 
proceedings must have ceased, otherwise there is no impediment in a Member State to initiate or continue the criminal proceedings for the same offense against the same person.

In case $\boldsymbol{M}^{26}$, the Court held that art. 54 CISA must be interpreted as meaning that an order for non-adjudication in the Member State in which a new prosecution for the same acts was committed against the person to whom the ordinance was given, unless new evidence against that person is found, must be regarded as a final judgment which prevents a new prosecution against the same person and for the same acts in another Member State. As regards the case of new evidence, the European Court of Justice stated that, taking into account the need to verify the genuineness of the elements relied on to justify a reopening, any new proceedings, against the same person and for the same acts, can be initiated only in the State where that ordinance was pronounced.

In Van Esbroeck ${ }^{27}$, the CJEU has established that a divergent legal classification of the same facts in two Member States can not prevent the application of art. 54 CISA and the non bis in idem principle, since the only relevant criteria is that of the identity of material acts, understood as the existence of a set of concrete circumstances indissolubly linked together, in time, in space, and by their object.

Regarding concurrent offenses, the CJEU decided in the Kraaijenbrink $^{28}$ case that in the situation where drug trafficking is being committed in one country and money laundering in another country, the non bis in idem principle does not apply, not being "the same facts". The Court considers that the different facts consisting, firstly, in the possession of money from narcotics trafficking in a State and, on the other, in the conversion of sums of money from drug trafficking to foreign exchange offices located in another Member State need not indicate the same fact in the sense of the provisions of art. 54 CISA only through the view of the fact that the competent national court finds that those facts are linked by the same criminal offense. In the Court's view, it is for the national court to assess whether the degree of identity and the connection between all the actual circumstances that have to be compared is of such a manner as to make it possible to establish that the same facts are involved.

In the case of Akerberg Fransson ${ }^{29}$, the CJEU ruled that the non bis in idem principle stated in art. 50 of the Charter of Fundamental Rights of the European Union does not preclude a Member State from imposing, for the same acts of non-compliance with its declaratory obligations in the field of value added tax, a tax penalty and a criminal sanction in so far as the first sanction does not have a criminal character, which must be verified by the national court. However, European Union law precludes a judicial practice which makes the national court obliged to disapply any provision contrary to a fundamental right guaranteed by the Charter, provided that this contradiction is clearly reflected in the Charter or the relevant case-law since it refuses the national court the power to fully appreciate the compatibility of that provision with the same Charter. National authorities and courts are therefore free to apply national standards for the protection of fundamental rights, provided that this application does not compromise the level of protection provided by the Charter, nor the supremacy, unity and effectiveness of Union law.

In Menci Luca ${ }^{30}$, the Advocate General argued that, in order for Art. 50 CFREU, there must be identity of material facts, irrespective of their legal classification, which serves as a basis for the application of fiscal and criminal sanctions. The non bis in idem principle is infringed in the case of the opening of a criminal procedure or the imposition of a criminal penalty on a person to whom a penalty for the same offense has been definitively

\footnotetext{
${ }^{26}$ Case 398/12, judgment of 5 June 2014.

${ }^{27}$ Case 436/04, judgment of 9 March 2006.

${ }^{28}$ Case 367/05, Judgment of 18 July 2007.

${ }^{29}$ Case 617/10, judgment of 26 February 2013. See also G. Tudor, Criminal Law. Harmonizing European legislation. Jurisprudence CJUE, PH. Universul Juridic, Bucharest, 2017, p.228.

${ }^{30}$ Case 524/15, judgment of 16 September 2015. Procedure reopened in January 2017 following the judgment of the ECHR of 15 November 2016 in the case concerning A and B c/a Norway. At the time of the consultation, only the Advocate General's conclusions were set out.
} 
imposed beforehand when it, despite its name, has a criminal character. These matters are to be verified by the court, taking into account the objective of the provision, its addressees and the legal interest protected - as well as the nature and severity of the sanction.

In Massimo Orsi andLuciano Baldetti ${ }^{31}$, the CJEU stated that art. 50 CFREU is not applicable where, in the case of administrative and criminal proceedings, administrative penalties and criminal penalties are applied for the same acts, tax penalties apply to a legal person and the criminal proceedings are brought against a natural person, even if he is the legal representative of the company (legally separate persons).

Article 4 of Protocol 7 to the ECHR guarantees that the non bis in idem principle is respected within the jurisdiction of the same State.

As an element of distinction, art. 54 CISA guarantees compliance with the non bis in idem principle only when the first proceedings were conducted in a State other than that in which the second proceeding is conducted.

For courts in the Member States, this bipartite system often leads to practical difficulties, as beyond the relatively different wording of the art. 4 of Protocol 7 ECHR and art. 54 CISA, the CJEU had different approaches to the interpretation of the idem element and the bis element ${ }^{32}$ to the ECHR. From a strictly theoretical point of view, it is possible that a criminal procedure is final according to the case-law of the Luxembourg Court, which makes the non bis in idem principle an incident, but a similar criminal procedure under national law is not judged definitively in Strasbourg, which excludes the application of the non bis in idem rule.

With regard to the term "final judgment", the CJEU has ruled that the decision must be final and binding within the meaning of the national law of the contracting State whose authorities has adopted it, and to ensure that that decision confers protection in that State on the non bis in idem principle (case-law Turansky).

With respect to element $\underline{\text { bis, }}$, the CJEU raised the following issues:

- if a first administrative sanction can be invoked in a subsequent criminal proceeding to make the non bis in idem rule applicable;

- if a first criminal proceeding is resolved with a non-adjudication solution ordered by the prosecutor, is the non bis in idem principle in the second criminal procedure applicable to the same offense?

The CJEU considered that the non bis in idem rule is also applicable to administrative sanctions with certain nuances. Thus, regarding the cumulation of administrative and criminal penalties, the Court has held that art. 50 ECHR does not preclude a Member State from imposing, for the same acts of non-compliance with VAT declarations, a combination of tax and criminal penalties (Fransson's case).

In order to determine whether the sanction is criminal or administrative, the Court referred to the Engel criteria (criteria used by the ECHR in the non bis in idem principle) and refers to:

o Legal classification of the offense in domestic law;

0 The very nature of the offense;

0 The nature and degree of severity of the sanction that a person is likely to endure.

Regarding these criteria, it is necessary to say that the Constitutional Court has excluded from the application in the field of administrative sanctions the characteristic

\footnotetext{
${ }^{31}$ Cases 217/15 and 350/15, Judgment of 5 April 2017.

${ }^{32}$ P. Craig, G. de Burca, European Union Law. Comments. Jurisprudence and Doctrine, PH. Hamangiu, 4th Edition, 2009, p.532-534.
} 
guarantees of the "criminal charge", taking into account that the presumption of innocence is strictly for the criminal process, and, as regards the contraventional liability, applies civil guarantees ${ }^{33}$.

According to judicial practice, prior to the entry into force of the New Code of Criminal Procedure, the non bis in idem principle and the abandoning of criminal charges apply $^{34}$.

The CJEU has stated that the non bis in idem rule is also applicable to those procedures whereby the Public Prosecutor, without the intervention of a court, renounces further prosecution and imposes certain obligations on the accused (Gozutok and Brugge case-law).

Regarding the idem element, CJEU considered that the only relevant criteria is the identity of the material acts, understood as the existence of a set of concrete circumstances, inextricably linked to each other, the divergent legal framing of the facts, and can not prevent the application of the non bis in idem ${ }^{35}$ principle. (Kraaijenbrink case-law).

\section{ISSUES ON NON BIS IN IDEM, BY REFERENCE TO THE COURT'S CONSISTENCY OR INCONSISTENCY}

\section{A) Problems regarding prescription}

The case of Gasparinii and others, in which the European Court finds that the non bis in idem principle is applicable when there is a final court judgment finding intervention on the limitation of criminal liability which prevents the initiation of proceedings in that Member State.

Analyzed from the perspective of our national law, we are talking about a decision to terminate the criminal proceedings for the intervention of criminal liability.

The conclusion of Court in Gasparinii, is seen in the European doctrine as a first inconsistency of the Court, since the same day the Court contradicted itself with the judgment in Van Straaten.

The criticism of the Gasparinii judgment is primarily about how the European cooperation instruments will work: knowing that they can benefit from this form of protection, a person, will try to use forum shopping; go to a state whose competence can to be activated by applying criminal law in space, knowing that the prescription has shorter deadlines in that state. For example, a romanian citizen who committed an offense in Romania (where prescription terms are extremely high) would flee to Italy (where prescription terms are mild), where they would activate the prescription regime.

Secondly, the nature of prescription must be analyzed. In some Member States (Belgium, France, etc.), the prescription is regulated as a procedural institution. In our national law, the prescription is not a procedural institution, it is not an exception, it is an institution of substantial law, and under these aspects, in our national law, Gasparinii, is not an inconsistency, fitting the material right, the court being no longer obliged to investigate the case when it finds the incidence of prescription, the case being settled by a solution for the termination of the criminal proceedings.

Regarding the institution of prescription at the Union level, the solutions given by the CJEU in cases Taricco (C-105/14) and MAS \& $\boldsymbol{M B}$ (C-42/17), we can conclude that the Luxembourg Court regards the prescription institution as a procedural institution, in which case, we can see an inconsistency.

\footnotetext{
${ }^{33}$ Decision 208 of 15 February 2011, published in Of. M. no. 218 of 30 March 2011 and Decision 652 of 17 May 2011, published in Of. M. no. 480 of 7 July 2011.

${ }^{34}$ Decision no. 632 of 23 August 2011 of the Oradea Court of Appeal, published in the Court of Appeal Bulletin no. 11/2011.

${ }^{35}$ See also Sergey Zolotukhin c/a Russia in this regard, judgment of 10 February 2009.
} 


\section{B) Problems on prosecutor's papers}

In joined cases Gözütok and Brügge, the CJEU stated that art. 54 CISA also applies to actions for the extinction of criminal proceedings, such as those in the main proceedings, whereby the Public Ministry of a Member State ends, without the intervention of a court, the criminal proceedings commenced in that State.

In the case of Miraglia, the CJEU stated that article 54 CISA does not apply to a decision by the judicial authorities of a Member State declaring the closure of a case after the prosecutor has decided not to continue the criminal proceedings for the sole ground that criminal proceedings have been initiated in another Member State against the same accused and for the same acts, in the absence of any substantive assessment.

In the Turansky case, the Luxembourg Court ruled that art. 54 CISA is not applicable to a decision whereby, after examination of the substance of the case, an authority of a Member State orders the cessation of criminal proceedings at a stage prior to the bringing of the criminal proceedings against a suspected person of committing an offense, if that decision of termination, under the national law of that State, does not definitively cease the criminal proceedings and does not therefore constitute an impediment to a new criminal prosecution for the same acts in that State.

In the Kossowski case, the Court held that a decision of the prosecutor's office to definitively cease the prosecution, subject to its reopening or cancellation without penalty, can not be qualified as a definitive decision within the meaning of those articles if, it is clear from that decision that the criminal proceedings in question were closed without a thorough criminal investigation being carried out, the absence of a hearing of the victim and of a possible witness indicating the lack of such an in-depth investigation.

From the above judgments we can see that an ordinance of the prosecutor who definitively quashes the criminal action after the ground's analysis takes the form of a final decision and can activate the non bis in idem principle even without any control by the court.

The Court has been consistent in all cases in which it defined the term of the judgment, namely the acts of the court and subject to certain conditions, the prosecutor's orders (even adopted without the involvement of a court).

In recent doctrine and practice, two camps were formed that contradict the fulfillment of the "final judgment" condition as it results from art. 6 Criminal Procedure Code, with regard to the prosecutor's orders. On one hand, it has been argued that any ordinance to classify or waive prosecution must be a final judgment and enter into force of judgment. On the other hand, the Supreme Court refuses to take account of Union practice and CJEU's rulings in the application of the principle, considering that the prosecutor's orders are not final judgments and thus can not lead to judicial authority ${ }^{36}$.

As far as we are concerned, we consider things to be nuanced, and in situations of this kind, we have to balance all the elements without pushing to the extremes. Thus, neither of the above opinions represent ideal solutions and are not sheltered by criticism, the more the Supreme Court's optics, which is also a source of conviction of Romania at the ECHR. Probably, the solution we propose, such as, in the sense of art. 6 Criminal Procedure Code, it is true that the prosecutor's orders are not per se final decisions, but it is no less true that, by exercising control over these ordinances, they would have been invested with "judgmental authority" , does not represent the "absolute ideal", and may lead likewise the other two opinions to delicate situations. Taking into account all the possible situations and issues, we still consider it to be the most balanced and necessary solution in our system.

\footnotetext{
${ }^{36}$ Decision no. 147 / RC dated April 3, 2017, pronounced by the Criminal Section of the Supreme Court.
} 


\section{APPLICATIONS OF THE NON BIS IN IDEM PRINCIPLE IN DOMESTIC LAW. CONSEQUENCES OF CJEU RULINGS}

In the doctrine (M. Udroiu, O. Predescu) it was appreciated that enjoy the res judicata: the resolutions or ordinances of the prosecutor of non-adjudication or non-adjudication in court ordered under art. 278/1 (1) Criminal Procedure Code of $1968{ }^{37}$.

The Supreme Court considered that a resolution of the Public Ministry's Office had come under the authority of a court of law because it was maintained by the courts in the procedure provided for in article 278/1 (1) Criminal procedure Code of 1968968 (Decision no. 354/ 2010 of 1 February 2010; Decision no. 215/2015 of 10 June 2015 and Decision no. 3903/2010 of 3 November 2010) ${ }^{38}$.

Court of Appeal of Cluj, in its decision 108 / R / 11 of February 2008, stated that offenses such as embezzlement under article 215/1 of the Criminal Code of 1969 and use in bad faith of the credit of the company under article 272 (2) of Law no. 31/90, can not be sanctioned as concurrent offenses, since it violates the non bis in idem principle ${ }^{39}$.

Decision no. 73/2011 ${ }^{40}$ of the Romanian Constitutional Court, stating that, in order for the non bis in idem principle to be applied, the person concerned must have been convicted, discharged or ordered to stop the prosecution for the deed which is again being prosecuted or judged. In the case of concurrent offenses, however, the offender shall be subject to a principal sentence, without thereby infringing in any way the provisions of art. 4 para. 1 of Protocol no. 7 to the Convention.

Decision no. $\mathbf{1 6} / \mathbf{2 0 1 6}^{\mathbf{4 1}}$, establishes that the money laundering offense is an autonomous offense and is not conditional upon the existence of a conviction for the offense from which the goods originate, and also not violating the non bis in idem principle in the case of the person's conviction for theft.

In recent doctrine, Prof. Gh. Mateuţ, said that, according to the Criminal Code of Procedure, the non bis in idem principle is also incident in the situation where the previous judgment is a final decision rejecting the complaint against the solution the prosecutor to classify or waive prosecution against the same person and for the same deed. Being the case of an appeal in annulment provided by art. 426 (i) Criminal Procedure Code, and when a subsequent judgment ordered the conviction, the waiver of the punishment or deferment of the punishment of a person for the same act for which the preliminary chamber judge had previously ordered the rejection of the complaint against the solution of the prosecutor for non-adjudication $^{42}$.

Thus, we can note that Court of Appeal of Oradea in the criminal decision no. 460 / A / 25 July 2017 (unpublished), found that the principle of non bis in idem is incident:

$\checkmark$ There is a final judgment on the grounds of the case in a Member State;

$\checkmark$ The new criminal trial has turned against the same person (eadem personae);

$\checkmark$ The new criminal proceedings concern identical facts or facts that are substantially the same (idem factum).

\footnotetext{
${ }^{37}$ M. Udroiu, O. Predescu, European Protection of Human Rights and the Romanian Criminal Procedure, PH. C.H.Beck, 2008, p. 941.

${ }^{38} \mathrm{~N}$. Volonciu and others, The Code of Criminal Procedure commented. Third Edition, Hamangiu Publishing House 2017 p. 24, cited from Bulletin of the Romanian Judicial Network in Criminal Matters, II / 2013 Hamangiu Publishing House, 2014.p. 3-7.

${ }^{39}$ www.legalis.ro

${ }^{40}$ Decision no. 73/2011 of 27 January 2011, published.

${ }^{41}$ Published in Of. M., Part I no. 654 of 25/08/2016.

${ }^{42} \mathrm{Gh}$. Mateuţ, The appeal in annulment, between the past and the present in the regulation of the Criminal Procedure Code in force, in Universul Journal nr.2 / 2016.
} 


\section{CONCLUSIONS: CONSISTENCY OR INCONSISTENCY OF THE CJEU IN THE CURRENT CASES OF LAW}

The non bis in idem principle is one of the most important, on which the international judicial co-operation in criminal matters is based, which is the result of the consequences of its interpretation and application.

Although the principle is recognized in all Member States' legislation, the European level is not well-established (although the abolition of borders and the approximation of EU Member States' legislation has created the premise of the widespread application of the principle).

That is why, on this segment, the Court of Justice of the Union has developed a rich jurisprudence.

The content of the non bis in idem ban was interpreted in two ways by the CJEU, that is, the same person can no longer be convicted of the legal classification given to a deed, but could be for another legal frame and, at the moment, the convicted from a case, can no longer be prosecuted and punished again for the same deed (on this segment, the Court was initially inconsistent). The Court of Justice of the European Union has pointed out that it is for the national courts to assess whether the degree of identity and the connection between all the actual circumstances to be compared is such as to make it possible to find that the same facts are involved and, if so, to apply the non bis in idem principle.

If initially the CJEU ruled that only a judgment on the grounds of the case would make the non bis in idem principle applicable, afterwards, the Court overturned its position, arguing that the non-adjudicatory orders given by the prosecutors allowed the application of that principle. The Luxembourg Court gave a positive answer also to a decision of the prosecutor to suspend on grounds of opportunity (waiving of prosecution), stating that it had the effect of a new prosecution.

Currently, the CJEU has consistent jurisprudence in the sense that any final settlement of a case - as a result of a material content check - given by a court or a prosecutor's office, applies the non bis in idem principle.

In the field of taxation, according to the recent case-law of the Court, a distinction is made between an administrative and a criminal act, the national courts being obliged to consider only one relevant criterion, that of the identity of the material acts, understood as the existence of an ensemble concrete circumstances inextricably linked to each other, in time and space, and by their object.

The Court practice is in full agreement with the ECHR, as evidenced by Sergey Zolotukhin v. Russia (judgment of 10 February 2009) and Butnaru and Bejan-Piser v. Romania (judgment of 23 June 2015).

At the present stage of regulation, an interpretation contrary to the non bis in idem principle would be likely to erode the right and affect international judicial cooperation in criminal matters.

We appreciate that, in the common judicial area, the European legislator should intervene by adopting regulations that would prevent any Member State from making use of the possibility of obtaining information involving international aid in order to institute criminal proceedings in abroad. A tolerance and acceptance by the Member States, based strictly on the principle of mutual recognition and mutual trust, is hard to understand, but if it were to take the form of a European regulation would create major benefits.

Until a legislative intervention has been made in the above-mentioned sense, in order to continue the process of European integration, the national courts in the Member States must comply with the provisions of Art. 50 of the Charter of Fundamental Rights of the European Union, by virtue of the principle of the primacy of Union law. 